Available online at

http://www.anpad.org.br/bar

\title{
Knowledge Transfer in Product Development: an Analysis of Brazilian Subsidiaries of Multinational Corporations
}

\author{
Dusan Schreiber * \\ E-mail address: dusan@feevale.br \\ Universidade Feevale \\ Novo Hamburgo, RS, Brazil. \\ Dalton Chaves Vilela Junior \\ E-mail address: dcvilela@hotmail.com \\ Fundação Centro de Análise, Pesquisa e Inovação Tecnológica - FUCAPI \\ São Leopoldo, RS, Brazil. \\ Lilia Maria Vargas \\ E-mail address: lmvargas@ea.ufrgs.br \\ Universidade Federal do Rio Grande do Sul - UFRGS \\ Porto Alegre, RS, Brazil. \\ Antonio Carlos Gastaud Maçada \\ E-mail address: acgmacada@ea.ufrgs.br \\ Universidade Federal do Rio Grande do Sul - UFRGS \\ Porto Alegre, RS, Brazil.
}

* Corresponding author: Dusan Schreiber

Rua Bolívia, 120, Pinheiros, São Leopoldo, RS, 93042-160, Brazil.

Copyright (C) 2011 Brazilian Administration Review. All rights reserved, including rights for translation. Parts of this work may be quoted without prior knowledge on the condition that the source is identified. 


\begin{abstract}
Several studies about knowledge transfer in multinational corporations have found that the process is influenced by factors such as absorptive capacity, tacit knowledge and power relations, all of which impact knowledge sharing strategies between corporate headquarters and foreign subsidiaries. A multiple case study of Brazilian subsidiaries of three multinational corporations using in-depth interviews, based on a conceptual model consisting of four propositions, was conducted to identify factors linked to the knowledge transfer process and to assess their influence on that transfer. The first proposition tries to assess explicit knowledge, primarily through the use of IT tools; the second analyzes the role of the subsidiary within the corporate network and how it influences the degree of knowledge sharing. The third assesses the influence of subsidiary absorptive capacity and the fourth analyzes the impact of worker exchange programs on knowledge sharing between headquarters and foreign subsidiaries. Study results confirm the four propositions and enable the identification of relationships between factors, especially explicit knowledge and worker expatriation as complementary factors in knowledge transfer strategies.
\end{abstract}

Key words: knowledge transfer; product development; multinational corporations. 


\section{Introduction}

Research on the knowledge transfer process in multinational companies is not a recent endeavor. The first studies on the subject date back to the 1960s, originally based on theoretical research on knowledge transfer and its coordination methods, from creation to sharing. Research on the subject has grown exponentially, extending the focus of the studies and revealing variables that influence the knowledge management process and the search for the factors that determine the effectiveness of knowledge transfer (Spender, 1996; Zander \& Kogut, 1995).

Some factors have been pointed out as being more important than others in this process, including absorptive capacity, knowledge explicitness, subsidiary roles, and personnel exchange. These factors influence the design of knowledge-sharing patterns, and define the strategies adopted by multinational companies to lead their worldwide knowledge transfer processes.

Early studies of the knowledge transfer process focused on transmission and sharing from headquarters to subsidiaries. This approach was justified by the importance of corporate headquarters to the internationalization process; since they held power and, in the majority of cases, had superior knowledge, technology and management processes, the goal was to replicate their model in the companies' subsidiaries. As subsidiaries have developed or acquired their own capabilities based on prior experience and knowledge, increasing their importance and power within the corporation, their participation in product and technology development has grown.

Few studies have focused on the search for variables associated with the knowledge transfer process in multinational corporations, combined with the characteristics, dimensions and origins of knowledge. It is assumed, from the contributions of Tsoukas (1996), Spender and Grant (1996), Grant (1996) and Simonin (2004), that many variables influence knowledge transfer, depending on the characteristics, dimension and origin of the knowledge, thus influencing the form of acquisition, absorption, registration and sharing of the knowledge. Based on a review of the literature on knowledge transfer, the objective of this paper is to identify the factors associated with the knowledge transfer process in the R\&D departments of multinational companies, built on the characteristics of R\&D knowledge, primarily in terms of project development. In order to further develop the subject, the paper analyzes a multiple case study of Brazilian subsidiaries of multinational corporations in the machinery and equipment sector. These cases provided an example of knowledge transfer between Brazilian subsidiaries and American and German headquarters, as well as between Brazilian and other subsidiaries.

Departing from the current literature, the cases studied herein reveal the dynamic nature of knowledge transfer design, depending on the set of technical and relational competences provided by the subsidiary to headquarter.

\section{Knowledge Transfer and Absorptive Capacity}

To properly understand the subject of this study, we first provide an overview of the concepts and features associated with knowledge, its transfer, and the corporate capacity to absorb knowledge.

\section{Knowledge definition and classification}

In the knowledge transfer process, the main function of management is to establish the necessary coordination for knowledge integration (Grant, 1996). The definition of knowledge used in this article is based on the concept suggested by Davenport and Prusak (1998, p. 6): "a fluid mixture of condensed experience, values, contextual information embedded not only in documents or repositories, but also in routines, processes, practices and organizational rules”. 
Knowledge is usually classified as either explicit or tacit. Explicit knowledge can be codified and easily communicated, and represents the entire set of knowledge that can be wholly articulated. As it is highly codified, explicit knowledge can be transmitted in a systematic manner and through formal language. Explicit knowledge is readily amenable to be processed by computer systems and stored in databases (Nonaka \& Takeuchi, 1997).

Tacit knowledge is defined by Polanyi (1983) as non-verbalized, non-articulated, intuitive knowledge. It is also highly contextual and specific, and has a personal quality that hampers its formalization and articulation (Dhanaraj, Lyles, Steensma, \& Tihanyi, 2004; Foss \& Pedersen, 2004; Nonaka \& Takeuchi, 1997; Spender, 1996). According to Martin and Salomon (2003), the greater the degree of knowledge tacitness, the more difficult its transfer.

\section{Knowledge transfer}

According to Faems, Janssens and Looy (2007), knowledge transfer flows from one individual (the knowledge holder) to another individual (who acquires it), and depends on the individuals' abilities and willingness to transfer it. It is worth noting that, to Davenport and Prusak (1998), in the case of knowledge transfer between business units of a single corporation, the knowledge does not need to be new to the company, but only to the receiving unit.

Besides transmission, knowledge transfer involves acquisition as well. Huber (1991) defines knowledge acquisition as the process through which knowledge is obtained, the assimilation of knowledge being conditioned by variables such as absorptive capacity, motivation of the recipient, and incentives for the transmitter. Mere availability of knowledge does not entail transfer. The key element in knowledge transfer is not the source of the original knowledge, but the recipient's perception of the utility and applicability of this knowledge in its operations. According to Garavelli, Gorgoglione and Scozzi (2002), the transfer process does not depend solely on the cognitive characteristics of the user that is the focus of the interpretation, but also on the way it is offered to the user, represented by the codification used to characterize that specific knowledge.

Acquired knowledge can be tacit, explicit, or a combination of both. According to Brown and Duguid (1991) and Tsoukas (1996), knowledge acquisition can also be the result of individual participation and interaction with tasks, routines, technologies, resources and people, within a specific context. Regardless of how individuals assimilate knowledge, the responsibility for providing a favorable context so that they will acquire it and apply it to their work rests with the organization.

Simonin (2004) suggested that the ambiguity of knowledge plays a critical role as a mediator between explanatory variables (tacitness, prior and later experience, complexity, cultural and organizational distance) and the result of the transfer process.

There are several barriers to knowledge transfer. Szulanski (1996) points to the lack of absorptive capacity, causal ambiguity, and relationship difficulties. Davenport and Prusak (1998) note other difficulties, namely: lack of trust; differences in culture, vocabulary and, theoretical landmarks; lack of a time and place for meetings; limited view of productive work; status and reward benefits for knowledge owners; a lack of absorptive capacity on the part of the recipient; belief that knowledge is the exclusive prerogative of certain groups; and lack of tolerance for errors or the need for assistance.

\section{Absorptive capacity}

A key aspect of knowledge transfer is absorptive capacity. To Cohen and Levinthal (1990), absorptive capacity is associated with the ability to explore external knowledge, transform it into innovation, and apply it towards business objectives. According to the authors, absorption is facilitated by proximity in knowledge base between transmitter and recipient, but does not depend solely on the individual capacity of its members; it is more than the sum of these capacities. 
According to Zahra and George (2002), absorptive capacity has two aspects: potential capacity and actual capacity. The former includes knowledge acquisition and assimilation, whereas the latter includes the transformation of knowledge and its actual use. Forcadell and Guadamillas (2002) stress how absorptive capacity requires similar levels of technical development for both transmitter and recipient, thus ensuring the quality of assimilation of the intervening knowledge. The quality of the process is tied to the specificity of the knowledge, the degree of formalization and the results obtained.

Henard and McFadyen (2006) argue that two complementary dimensions of accumulated knowledge and absorptive capacity—depth and range-are especially important for R\&D activities. The depth of accumulated knowledge is indicative of prior investment to acquire relevant knowledge. Range, in turn, concerns the application of accumulated knowledge. The existence of R\&D knowledge optimizes the development and creation of new knowledge and new products.

Through a quantitative structural equation modeling study, Murovec and Prodan (2009) sought to ascertain which factors influence absorptive capacity in multinational corporations. Their results validated an absorptive capacity model built on two dimensions: (a) demand-pull and (b) science-push. The evidence confirmed the hypothesis that internal R\&D activities have a favorable effect on absorptive capacity in both dimensions and that external R\&D use is unrelated to the development of absorptive capacity in organizations. Furthermore, the study confirmed that absorptive capacity is based more on demand than on scientific progress.

Several elements improve absorptive capacity. They include: similarity between knowledge processing systems, organizational structures, experience solving similar problems (Lane \& Lubatkin, 1998), trust, organizational processes, ability to apply knowledge (Lane, Salk, \& Lyles, 2001), learning capacity, goals agreed upon by partners, training (Lyles \& Salk, 1996), and long-term cooperation (Björkman, Barner-Rasmussen, \& Li, 2004; Daghfous, 2004).

\section{R\&D Internationalization and Knowledge Transfer in Multinational Corporations}

In Brazil, as in many developing nations, much of the R\&D work is conducted by Multinational Corporations (MNCs). Subsidiaries have different roles within corporations, from simple manufacturers that only replicate what is ordered by headquarters to developers of new technologies for worldwide use (Simonin, 2004). According to Gupta and Govindarajan (2000), if a corporation wants to compete in the international market, it will require knowledge-based intangible assets. Furthermore, according to Spender and Grant (1996), knowledge transfer has a strategic dimension and importance within the corporation as well as in the relationship between external firms.

According to Szulanski (1996), multinational corporations are more than just repositories of the brands; they also act as channels through which knowledge is transmitted to subsidiaries, from them back to headquarters, and also between the various subsidiaries. Since MNCs can develop knowledge in one place and apply it in others, the competitive advantage of multinational organizations depends on their ability to facilitate and co-ordinate knowledge transfer within the firm. As defined by Huber (1991), the organizational memory acquired by the technology used to transmit information from past experience must be activated in a way that minimizes implantation problems, difficulties and risks in the transmission.

According to Simonin (2004), the establishment of subsidiaries is a form of internationalization, benefiting from cheaper local labor and lower raw material costs. In a few situations, subsidiary acquisition and/or implantation is prompted by other reasons, such as interest in acquiring local knowledge or technology, breaking into a new market, using the distribution network of the acquired company, and obtaining access to government-subsidized sources of $R \& D$ funding. These cases can feature a reversal of the usual course of knowledge transfer: knowledge migrates from the subsidiary to headquarters. Organizational learning has become a subject of interest to headquarters in 
consolidating this flow, as well as in directing it among subsidiaries, promoting their upgrade (Dhanaraj et al., 2004).

Birkinshaw and Hood (1998) and Rugman and Verbeke (2001) point out that networks of globally distributed subsidiaries constitute a potential and important source of competitive advantage for multinational corporations. According to Frost (2001), by accessing the repository of knowledge embedded in the network of subsidiaries, multinationals can exploit or combine them to explore new niches and develop new abilities. This argument highlights transfer competence as the core challenge for management in multinationals (Gupta \& Govindarajan, 2000; Szulanski, 1996; Zander \& Kogut, 1995).

According to Criscuolo (2004), R\&D internationalization remains a controversial subject, both in the corporate world and in academia. Decisions to centralize R\&D activities or spread them out among subsidiaries are fraught with complexity due to the many objective and subjective variables that must be taken into account in the analysis process, and have therefore been interpreted from many standpoints in terms of their advantages and disadvantages. Advantages include optimization of the new product development process, faster customization of technology solutions for local customers and access to foreign centers of technological excellence in certain areas of knowledge. Disadvantages include the potential for increased costs due to geographic dispersion of R\&D activities, jeopardizing budget control, increased risk of losing confidential information to competitors in the host countries of subsidiaries, and the possibility of a knowledge and technology gap between headquarters and subsidiaries.

Gomes (2003) believes that the decision to internationalize or centralize R\&D must take into account the specificity of the relevant product or service, the product life cycle model, and the transnational corporation management model. Individuals choose between available alternatives based on an interpretation of the available data on intervening variables, within the cognitive constraints of rationality. Asakawa (2001) found that the R\&D internationalization process gave rise to a high degree of tension within the corporation, more due to information sharing aspects than to managerial decision-making autonomy.

To Szulanski (1996), research indicates that barriers to knowledge transfer include motivational factors, among others. A subsidiary may hesitate to transfer knowledge to another one for fear of losing its position of superiority, or because rewards would be unsatisfactory when weighed against the efforts and costs expended in the process of knowledge generation

Gupta and Govindarajan (2000) found that the flow of knowledge directed to subsidiaries is positively associated with the depth and quality of transmitting channels, encouraging the assimilation of knowledge and recipient capability to absorb it.

Several assessments have focused on the extent to which barriers and difficulties in the relationship between subsidiaries affect knowledge transfer. To Orr and Sohal (1999), barriers to technology transfer are minimized within multinational corporations mainly due to prior planning and preparation for the transfer process. However, knowledge transfer entails high costs for the transferring subsidiary. To better understand the knowledge transfer process within multinational corporations, the authors developed a set of four propositions.

\section{Technological forms to transfer explicit knowledge}

According to Zander and Kogut (1995), the dichotomy between tacit and explicit knowledge is based on the ability and forms of knowledge to be codified and transmitted. When the possibility of knowledge codification is greater and its transmission is easier, its assimilation and sharing are also greater. Thus, standardization and set procedures facilitate knowledge transfer in an explicit form. In this context, information systems that enable information continuity and exchange represent important tools, making knowledge more explicit and facilitating its transfer. 
As noted by Scott (2000), information technology speeds up information exchange and makes it possible for information to cross organizational borders, making it an important tool for interorganizational knowledge. However, the author notes that lack of trust hampers information exchange, even when tools to make this exchange possible are available. According to Narteh (2008), long-standing relationships increase trust and help boost knowledge transfer. In the MNC setting, the fact that knowledge is kept within the corporation may increase trust and allow the implementation of shared software solutions to make knowledge transfer between subsidiaries and headquarters easier.

Malhotra, Gosain and Sawy (2005) also highlight the positive impact of information systems on absorptive capacity to enable assimilation and transformation of transferred knowledge. This leads us to the following proposition:

P1: Tools that make knowledge explicit enable its transfer within multinational corporations.

\section{The role of subsidiaries and their absorptive capacity}

In an attempt to analyze knowledge transfer between headquarters and subsidiaries, Song and Shin (2008) studied the process in various semiconductor manufacturers. Their research showed that MNCs that developed their own knowledge and technology paths can adopt knowledge management processes, somewhat contradicting the current trend. The authors state that organizations that hold market leadership and master technology in their home countries tend to look for knowledge overseas, due to the dearth of corporate learning opportunities for headquarters in the organization's home country. They also found that the level of knowledge exploitation in foreign countries grows and then ebbs as the gap between the technological profile of the organization and that of its new market is bridged by direct investment.

According to Li, Ferreira and Serra (2009), innovative capacity in global corporations no longer depends on the capacity to innovate and transfer knowledge and technology from headquarters to a network of subsidiaries, but is instead increasingly reliant on the capacity for cooperation among corporate subsidiaries. The authors stress that cooperation between subsidiaries is determined by the company's international strategy and organizational structure and by the social relationship between subsidiaries; if the subsidiary profile favors inter-unit competition rather than cooperation, the knowledge sharing and technology transfer process will lead towards failure.

Subsidiaries can play various strategic roles. In a study of Brazilian subsidiaries, Boehe (2007) identified five different roles with respect to innovation: local adaptors, nascent innovators, local innovators, innovators for emerging markets, and global innovators. Plants focusing on the local market are usually more autonomous than global innovators, but feature less innovation. Another finding of that study is that subsidiaries capable of developing products for emerging markets can become regional centers. As noted by Oliveira, Boroni and Guevara (2009), strategic information exchange improves the standing of subsidiaries within the corporation, making them more relevant to headquarters.

Mudambi and Navarra (2004) point out the increasing importance of subsidiaries in knowledge generation. Currently, a substantial portion of organizational knowledge is created by subsidiaries. Knowledge increases the power of subsidiaries in their interaction with headquarters, modifying the existing relationship type. Subsidiaries that achieve a superior position in the relationship start to stand up for their interests. In turn, opportunism and the search for superior profits may become a concern for the headquarters in relation to these subsidiaries. Dhanaraj, Lyles, Steensma and Tihanyi (2004) corroborate this finding, stating that the bargaining power of the subsidiary to keep and increase its share in the earnings generated from its operation depends on the nature and pattern of the knowledge flow.

Some subsidiaries started to take on greater responsibilities, both in product management and in the geographic scope of new markets, according to Dhanaraj et al. (2004) and Birkinshaw and Morrison (1995). Brazilian subsidiaries have also expanded their activities within their parent 
corporations. Automotive industry studies carried out by Consoni (2004) detected a shift from simple product adaptation towards greater participation in global product development in some automakers operating in Brazil. However, the author stresses that these subsidiaries do not take part in organizational R\&D activities, and are instead confined to new product development. However, core R\&D units are rarely located in Brazil, as noted by Cassiolato, Lastres, Szapiro and Vargas (2001), and the role of local subsidiaries - despite their potential to contribute far more towards R\&D activities_-is still limited, also according to Hiratuka (2005).

Subsidiaries have also extended the set of activities that was originally assigned to them (such as sales, technical and assembly services), developing and contributing to the growth of processes with greater strategic value, such as $\mathrm{R} \& \mathrm{D}$, component production, marketing strategy, and administrative support activities (Gupta \& Govindarajan, 2000). Participation of subsidiaries in the corporate knowledge exchange process is influenced by their absorptive capacity, as set forth by Monteiro, Arvidsson and Birkinshaw (2008). Poor absorptive capacity leads to the isolation of the subsidiary and, consequently, lower participation in knowledge creation and transfer. This leads us to the following propositions:

P2: The role of subsidiaries within the corporation influences the degree of knowledge transferred between it and the other components of the multinational corporation, including headquarters.

P3: The absorptive capacity of subsidiaries influences the degree of knowledge transferred between it and the other components of the multinational corporation, including headquarters.

\section{Worker exchange programs}

Interpersonal networking is a key source of knowledge, as reported by authors such as Corno, Reinmoeller and Nonaka (1999). Interpersonal contacts increase trust and allow an exchange of tacit knowledge that would be impossible without physical proximity. A Noorderhaven and Harzing (2009) study of multinational corporations concluded that social interactions have a positive effect on the flow of knowledge between subsidiaries and headquarters, and that poor subsidiary capacity is associated with a low intensity of knowledge flow between other subsidiaries. The latter authors also suggest that, despite their high cost, business trips and contacts are part of the knowledge transfer toolkit and should not be neglected.

The knowledge transfer flow has grown and become more complicated. Keller and Chinta (1990) state that some strategies could be used to improve technology transfer capability, such as decentralized matrix-type organizational structures for easier exchange of ideas; interaction between subsidiaries, in which professionals from one subsidiary spend a certain time at another to learn or to transfer knowledge; hiring staff from countries in which the subsidiary is already established or plans to become established, in order to assimilate cultural differences; and obtaining an understanding of local and idiosyncratic control, compensation and goal policies .

According to Björkman, Fey and Park (2007), international experience helps workers expand their knowledge base and network of contacts. Expatriate employees thus serve as conduits for knowledge transfer, since they take knowledge with them and bring it back to their units of origin. The knowledge transfer process should therefore include the flow of personnel and the source of the knowledge to be transferred, as noted by Narteh (2008). According to Minbaeva, Pedersen, Björkman, Fey and Park (2003), the greater the number of expatriate employees in a subsidiary, the greater the level of knowledge transferred.

Björkman, Barner-Rasmussen and Li (2004) point out that subsidiaries are not interested in incurring expenses and losing their experts for the duration of the transfer process. To encourage knowledge transfer and show its importance, headquarters should value the initiative to implement this new design while evaluating the subsidiary and employ methods to foster socialization between subsidiaries. This leads us to the following proposition: 
P4: The flow of people from one subsidiary to the other components of the multinational corporation influences knowledge transfer to and from subsidiaries.

The previous four propositions have guided the development of the conceptual model in Figure 1 , which includes the various factors identified as influencing knowledge transfer within multinational corporations:

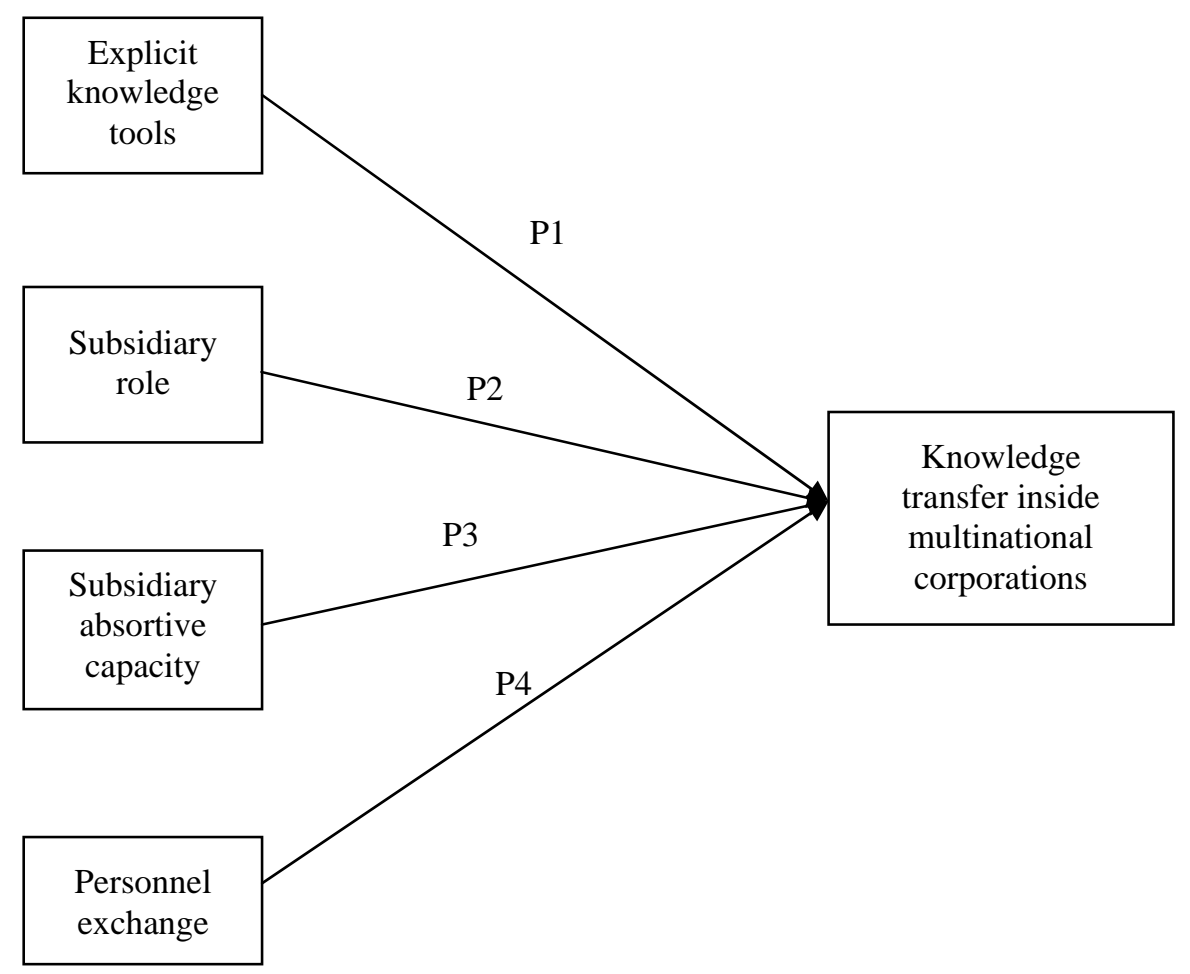

Figure 1. Factors that Influence MNCs Subsidiaries Knowledge Transfer.

\section{Methodology and Description of Empirical Studies}

In order to better understand the subject, we conducted a multiple case study based on a convenience sample of three subsidiaries of multinational corporations in the machinery sector for the local and export markets. This choice of method is justified by the exploratory and descriptive nature of the study, as it seeks to gain an understanding of the knowledge and technology transfer process between international headquarters and Brazilian subsidiaries. The focus on factors that influence knowledge transfer sets this study apart from those by Consoni (2004) and Monteiro et al. (2008), among others, which have focused on identifying the contribution of subsidiaries to the R\&D function. The authors chose to study subsidiaries so as to better understand this phenomenon.

The case study portion of our research was conducted in two stages: first, a technical visit, with presentations about the organizations and tours of the plants, second, in-depth interviews with engineers and $R \& D$ managers, for a total of three interviews with a mean duration of 90 minutes each.

As recommended by Yin (2001) and Lee (1998), interviews were scripted on the basis of case study protocols. Information obtained from the interviews was categorized using the axial coding method and later reconstructed.

Interviews were semi-structured, with questions based on the subjects of our literature review, allowing interviewees to reflect and develop a narrative thread that included not only their present situation but also the history underlying the current context. The first question involved the importance 
of knowledge to the subsidiary within the corporation, and how R\&D and engineering knowledge is used and made explicit for new product and process development. The other questions asked what factors within the corporation help knowledge transfer or pose a barrier to it; the authors emphasized that technical knowledge was the focus at that moment. The interview was concluded with questions about some characteristics of the organization and the importance of the subsidiary to the corporation. Interviewees were barred from disclosing pieces of information regarded as confidential, such as the makeup of R\&D teams, for even a general overview of this data could make the companies identifiable to their competitors, jeopardizing their strategic positioning with regard to product and process innovation.

Case studies were conducted at the following companies:

1. Alpha Company is a subsidiary of a multinational corporation headquartered in the United States which manufactures agricultural machinery sold in more than 140 countries. Alpha Company has two plants in Brazil. The unit studied is located in the Porto Alegre metropolitan area. Alpha manufactures several brands and has more than 2,000 workers in its Brazilian plants.

2. Beta Company is headquartered in Germany and has plants in many other countries. Beta manufactures chainsaws, scythes and other agricultural implements. The Brazilian plant was the first to be built outside its country of origin; it was established in 1973 and is also located in the Porto Alegre metropolitan area. Beta employs roughly 1,200 workers in the plant studied.

3. Gamma Company manufactures air conditioners. It was founded by Brazilian entrepreneurs in the 1930s, and, in 1983 merged with a major American group present in more than 170 countries. Gamma has about 950 workers in Brazil.

The cases studied are based on the relation between the product development sector of these subsidiaries and their headquarters, and also with other subsidiaries, primarily a Gamma Company subsidiary located in Saudi Arabia. The subsidiaries studied are characterized by active involvement in product development, but relatively little importance within the parent corporation's overall $R \& D$ activities.

This paper has several limitations inherent to the case study method, such as the impossibility of providing statistically significant results; only a qualitative generalization of results is possible. It was also limited by the small number of study cases and the potential for biases introduced by interviewing only employees in a single sector of the company, which precludes, for instance, extrapolating the results for the entire R\&D sector. It is also impossible to directly replicate results in other countries, since our analyses had the Brazilian reality in mind throughout the process.

\section{Results}

The three subsidiaries studied here had similarities and differences with respect to knowledge development and transfer.

Knowledge characteristics were found to have influence on transfer difficulties, as noted by authors such as Polanyi (1983) and Nonaka and Takeuchi (1997). At Alpha, we found the knowledge transfer process to be facilitated by the high degree of explicit knowledge. It was easier in more technical areas than in softer ones, as reported by Park and Kim (2005). Beyond process and products standardization with ISO standards, the company has activity and procedure guidelines drafted in such a way as to decrease the possibility of misinterpretation and, consequently, ensure their proper application in the manufacturing process. Another explicit knowledge tool facilitating knowledge exchange is the use of a single integrated software solution and access to global databases, corroborating the points proposed by Scott (2000). 
At Beta, the relevance of explicit knowledge is also stressed by technical standards and schematics that lay out the actual, proper way of performing functional tests, manufacturing, and integrating components. This importance is justified by the tacitness of expert knowledge in some technical subjects, derived from their experience. The R\&D manager recognizes that explicit knowledge is a priority only for final tests results, processes and drawings - in other words, for recording best practices-but the memories or history of experts, which constitutes their expertise, is not codified as well as know-how details, which are restricted to more evident aspects. This stresses the importance of tacit knowledge even in engineering-related product development activities, corroborating the findings of Foss and Pedersen (2004) and Garavelli et al. (2002), among others.

Gamma Company was characterized by a noticeably high degree of standardization, which made technology transfer easier. Transfer depends on the laboratory infrastructure of each unit that will receive technical knowledge. In an attempt to optimize financial resources, Gamma chooses to have only one specialist for certain technical aspects. Unlike Beta Company, at Gamma explicit knowledge is a priority. The firm tries to decrease the high degree of knowledge tacitness, thus minimizing company dependence on individual knowledge. It is also clear for higher management that, in order to transform tacit knowledge into explicit knowledge, previous conceptual/technical leveling is a vital condition, ensuring the understanding of test recording and technical training processes. After knowledge has been made explicit, it is recorded and shared with the corporate R\&D area through the company intranet. This fact underlines the importance of information systems in the knowledge transfer process, as noted by Malhotra et al. (2005). As stressed by P1, multinational corporations have developed and utilized tools to make knowledge explicit. The goal is to facilitate its transfer, since explicit knowledge is more easily transferred; however, the impossibility of making certain elements explicit and the importance of tacit knowledge are perceived in a different way by each MNC.

Gamma, which is specialized in manufacturing, stands out as a source of technological diffusion for a specific family of products. The presence of a worldwide lead design center in Brazil gives it a prominent position in this family, and also places it in a position of superiority to other countries in other product lines. We perceived a major cost concern underlying the technology transfer decision, as reported by Simonin (2004). The company tends to prioritize lower purchase prices; the company opts for off-the-shelf solutions instead of investing in internal production whenever possible. This has become more frequent due to Brazilian monetary policies, which keep the local currency overvalued and has hindered the competitiveness of the Brazilian industry. If, on the one hand, costs have curtailed Brazilian competitiveness, on the other, relative cost increases have forced Brazilian subsidiaries to fight for a greater share in the product development function, as noted by Consoni (2004).

In the early years of internationalization into the Brazilian market, companies mostly sought cost advantages, but Brazil has lost much of its competitiveness in that respect. However, it has become stronger in technical competences. Plant performance in terms of product development has increased. Alpha and Gamma are the main developers and manufacturers of certain products within their respective corporations. These, however, are low-technology products. Beta is increasing its participation in product development within the corporation because of the lower cost of Brazilian engineers compared to German ones, even though Brazilian engineers are no less technically qualified. Beta Company uses a competition policy to determine which plant will be responsible for manufacturing certain products. The Brazilian subsidiary stood out in some products and currently supplies some parts to the entire corporation. However, major decisions on new product development, as well as some tests, are invariably carried out at headquarters as a security and strategic control measure, preventing subsidiaries from growing in importance and power, as noted by Dhanaraj et al. (2004).

Many decisions are made globally, and the subsidiary simply follows the policies set by corporate headquarters. These decisions reduce barriers that could otherwise hamper technology transfers. Alpha and Beta declared that some decisions are imposed on them by the corporation, and they simply follow what has been defined without any sort of resistance. Future needs entail a 
commitment to absorb and apply transmitted knowledge in the best possible way. Alpha admitted that there is competition for resources among subsidiaries, but not to any great extent. Gamma declared that there are some barriers between subsidiaries, such as sluggishness in providing information, but these barriers neither affect decision-making nor jeopardize projects. By developing a more significant role within the corporation and taking on the development of certain products, the subsidiary grows in importance as a source of knowledge, as underlined by P2, influencing other subsidiaries and even headquarters. For a subsidiary to strengthen its role, however, it needs to develop a knowledge base, i.e., an absorptive capacity that enables the input and absorption of new knowledge, corroborating P3.

At Alpha, personnel exchanges are accompanied by a constant exchange of knowledge, even before workers return to their original subsidiaries, through e-mail and conference calls. Although expatriation is used as a means of knowledge transfer, the number of workers moving from one country to another is quite small, so a solid background that ensures high absorptive capacity is viewed as key for reducing dependence and the costs of expatriation.

Beta placed particular emphasis on the importance of personnel exchange between subsidiaries. Expatriation is planned beforehand: before an employee moves to another country, a checklist is prepared (primarily with a technical focus) of what must be learned, what must be done and what will be used upon the employee's return. The existence of plans, procedures, processes and guidelines facilitates knowledge transmission. Knowledge is relayed to other personnel in the subsidiary through presentations when the expatriated professional returns. This exchange program seeks to speed up the sharing of technical knowledge.

Gamma corporation utilizes personnel travel to other subsidiaries for specific events and when otherwise necessary, in an attempt to reduce project deadlines and risks. Participation, including physical presence, from the very beginning of a project, helps professionals better understand the project as a whole, corroborating the findings of Björkman et al. (2004), Daghfous (2004), and Narteh (2008), which stressed the importance of long-term relationships due to their beneficial effect on absorptive capacity.

The physical presence of professionals in other countries for knowledge sharing is not perceived as a necessity for knowledge transfer, but it plays a useful role in aligning definitions, standards, goals and priorities in terms of product development - that is, social contact is important for the exchange of some knowledge, as noted by Corno et al. (1999), partially corroborating P4.

The results described above are associated with the four propositions. Table 1 summarizes the main features of the three organizations studied herein.

Table 1

Features of Alpha, Beta and Gamma Companies

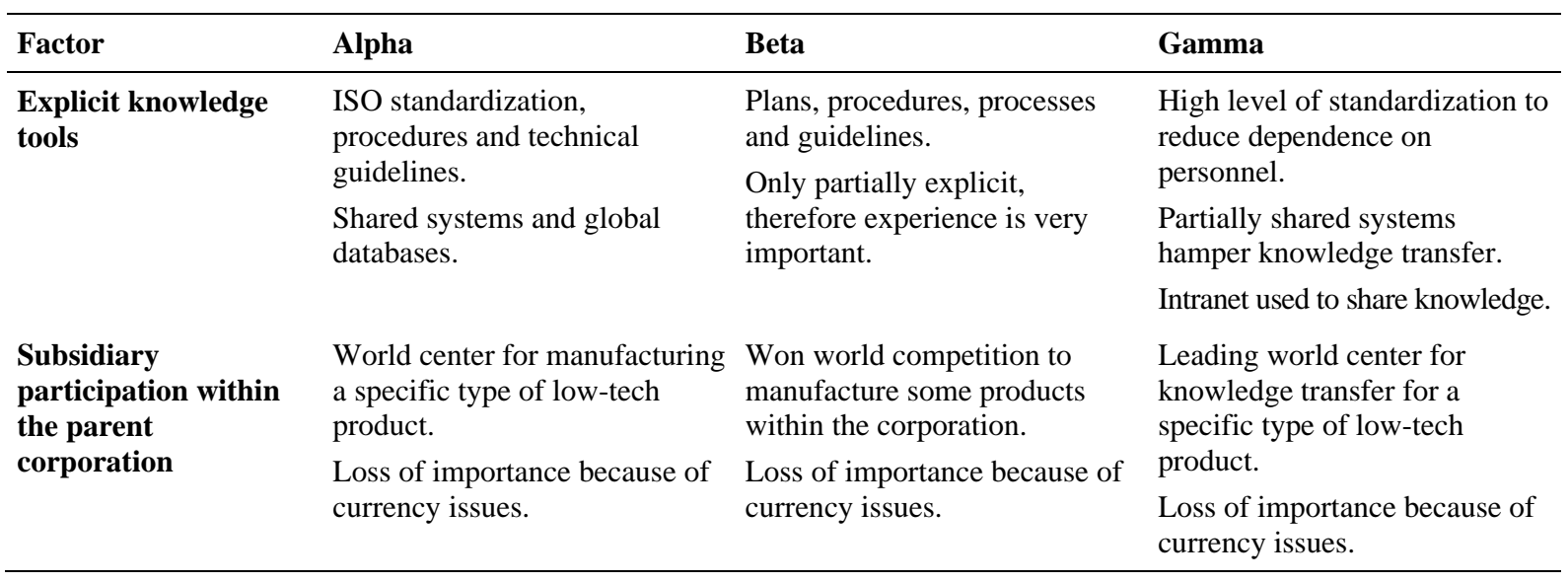




\section{Table 1 (continued)}

\begin{tabular}{llll}
\hline Factor & Alpha & Beta & Gamma \\
\hline Absorptive capacities & $\begin{array}{l}\text { High level of technical and } \\
\text { absorptive capacities }\end{array}$ & $\begin{array}{l}\text { High-level of technical and } \\
\text { absorptive capacities plus } \\
\text { lower cost as compared to the }\end{array}$ & $\begin{array}{l}\text { Specialists in some products. } \\
\text { HQ country. }\end{array}$ \\
Personnel exchange & $\begin{array}{l}\text { Personnel spend some time in } \\
\text { other countries, but constantly } \\
\text { exchange information. }\end{array}$ & $\begin{array}{l}\text { Preparation (including use of a } \\
\text { checklist) before expatriation. } \\
\text { On-the-job training. } \\
\text { Presentations when returning to } \\
\text { the country. }\end{array}$ & $\begin{array}{l}\text { Based on specific projects, } \\
\text { mainly for definition purposes } \\
\text { rather than knowledge transfer. }\end{array}$ \\
\hline
\end{tabular}

\section{Conclusions}

The proposed factors influence knowledge transfer within MNCs. Global centers diffuse technology to others, but must also be prepared to receive it. Intraorganizational transfers induce the diffusion of knowledge. Headquarters tend to lose some importance as subsidiaries come to develop more knowledge and technology, as proposed by Gupta and Govindarajan (2000) and Dhanaraj et al. (2004). The subsidiaries studied in the present case series are conducting novel activities and are even undertaking product development, increasing their own knowledge and that of the corporation as a whole.

To increase the development of its own knowledge, subsidiaries must pay attention to the four propositions of this paper.

The technological capabilities of subsidiaries have been a key element in the three corporations' decisions on where to develop and where to transfer knowledge. Perceptions such as that of Beta Company, which stated that Brazilian engineers are technically competent and have lower labor costs than German ones, can provide opportunities for increased Brazilian participation in corporate R\&D. The subsidiaries enable the development and transfer of its own knowledge, increasing its power and influence inside the corporation.

Explicit knowledge facilitates knowledge transfer, and can often, but not always, replace expatriation. As knowledge expatriation is perceived as a tool to allow tacit knowledge transfer, making knowledge explicit can, sometimes, substitute for expatriation. However, making knowledge explicit and expatriation can be complementary. Though in most cases corporate headquarters retain the power to decide which plant will be responsible for knowledge and product development, Brazilian subsidiaries have increased their capabilities, through the development of certain products and by transferring knowledge to other subsidiaries. If the corporate perception of Brazil as a country with a high-quality technical workforce persists, the importance of Brazilian subsidiaries to the R\&D function of their parent companies will tend to increase.

Since cost savings are no longer such a substantial competitive advantage for Brazilian subsidiaries, these units are trying to increase their capacity for new knowledge development, as exemplified in this study by Beta Corporation, which is responsible for the development of a few novel products. However, corroborating the findings of Consoni (2004), subsidiary participation in corporate R\&D was found to be limited to new product development. The level of differentiated knowledge is thus not sustainable, since other subsidiaries or external competitors could easily copy most developed products. Therefore, developing the capability to increase participation in R\&D activities is very important for the survival of subsidiaries. 
The authors believe that the present article contributes to a better understanding of the knowledge and technology management process, especially in product development projects conducted by multinational corporations with local operations in Brazil, improving current understanding of the variables that influence headquarter-to-subsidiary knowledge transfer models. Therefore, we would like to stress our identification of the factors associated with knowledge transfer for new product development: type of transferred knowledge (explicit or tacit), subsidiary roles, absorptive capacity, and personnel exchange. Research results show that the development and enhancement of local technical competences has strengthened the role of subsidiaries in the global corporate network of multinationals.

This change in conditions has led to an increased sense of trust in headquarters, enabling them to delegate to subsidiaries greater autonomy in R\&D management, promoting knowledge transfer and allowing subsidiaries to conduct more sophisticated, critical processes in terms of new product development. Thus, we can conclude that these results allow us to identify the following as factors associated with the knowledge transfer process in the new product development area of the three subsidiaries of MNCs studied herein: the enhancement of technical competences of Brazilian professionals, which has had a positive impact on the local absorptive capacity; support infrastructure, such as the IT area; the standardization of internal procedures; and the transfer of cultural values from headquarters.

Extending this research to other subsidiaries can bring new contributions, as can comparisons of Brazilian subsidiaries with other subsidiaries of the same corporation in different countries. Other studies could be carried out to analyze types of knowledge other than Product Development knowledge in the same companies, in an attempt to detect difficulties and barriers to transfer. The manner in which cultural differences and political influences affect knowledge transfer could also be an interesting subject for further research.

\section{Received 11 September 2009; received in revised form 19 January 2011.}

\section{References}

Asakawa, K. (2001). Evolving headquarters subsidiary dynamics in international R\&D: the case of Japanese multinationals. R\&D Management, 31(1), 1-14. doi: 10.1111/1467-9310.00192

Birkinshaw, J. M., \& Hood, N. (1998). Multinational subsidiary evolution: capability and charter change in foreign-owned subsidiary companies. The Academy of Management Review, 23(4), 773-795. doi: 10.2307/259062

Birkinshaw, J. M., \& Morrison, A. J. (1995). Configurations of strategy and structure in multinational subsidiaries. Journal of International Business Studies, 26(4), 729-753. doi: 10.1057/palgrave.jibs.8490818

Björkman, I., Barner-Rasmussen, W., \& Li, L. (2004). Managing knowledge transfer in MNCs: the impact of headquarters control mechanisms. Journal of International Business Studies, 35(5), 443-455. doi: 10.1057/palgrave.jibs.8400094

Björkman, I., Fey, C. F., \& Park, H. J. (2007). Institutional theory and MCN subsidiary HRM practices. Evidence from a three-contry study. Journal of International Business Studies, 38(3), 430-446. doi: 10.1057/palgrave.jibs.8400267

Boehe, D. M. (2007). Desenvolvimento de produtos em subsidiárias de empresas multinacionais no Brasil. Revista de Administração de Empresas, 47(1), 33-45. doi: 10.1016/j.intman.2007.08.002 
Brown, J. S., \& Duguid, P. (1991). Organizational learning and communities-of-practice: toward a unified view of working, learning and innovation. Organization Science, 2(1), 40-57. doi: $10.2307 / 2634938$

Cassiolato, J. E., Lastres, H. M., Szapiro, M. H., \& Vargas, M. A. (2001, June). Local systems of innovation in Brazil, development and transnational corporations: a preliminary assessment based on empirical results of a research project. Proceedings of the Druid, Kopenhagen, Denmark, 6.

Cohen, W. M., \& Levinthal, D. A. (1990). Absorptive capacity: a new perspective on learning and innovation. Administrative Science Quarterly, 35(1), 128-152. doi: 10.2307/2393553

Consoni, F. L. (2004). Da tropicalização ao projeto de veículos: um estudo das competências em desenvolvimento de produtos nas montadoras de automóveis no Brasil (Tese de doutorado). Universidade Estadual de Campinas, Campinas, SP, Brazil.

Corno, F., Reinmoeller, P., \& Nonaka, I. (1999). Knowledge creation within industrial systems. Journal of Management and Governance, 3(4), 379-394. doi: 10.1023/A:1009936712733

Criscuolo, P. (2004). R\&D internationalisation and knowledge transfer: impact on MNEs and their home countries (Doctoral dissertation). Universiteit Maastricht, Maastricht, Holanda. Retrieved December 14, 2004, from http://www.merit.unu.edu/publications/phd/PCriscuolo.pdf

Daghfous, A. (2004). Organizational learning, knowledge and technology transfer: a case study. Learning Organization, 11(1), 67-83. doi: 10.1108/09696470410515733

Davenport, T., \& Prusak L. (1998). Conhecimento empresarial. Rio de Janeiro: Campus.

Dhanaraj, C., Lyles, M. A., Steensma, H. K., \& Tihanyi, L. (2004). Managing tacit and explicit knowledge transfer in IJVs: the role of relational embeddedness and the impact on performance. Journal of International Business Studies, 35(5), 428-442. doi: 10.1057/palgrave.jibs.8400098

Faems, D., Janssens, M., \& Looy, B. V. (2007). The initiation and evolution of interfirm knowledge transfer in R\&D relationships. Organization Studies, 28(11), 1699-1728. doi: $10.1177 / 0170840606082222$

Forcadell, F. J., \& Guadamillas, F. (2002). A case study on the implementation of a knowledge management strategy oriented to innovation. Knowledge and Process Management, 9(3), 162171. doi: $10.1002 / \mathrm{kpm} .143$

Foss, N. J., \& Pedersen, T. (2004). Organizing knowledge processes in the multinational corporation: an introduction. Journal of International Business Studies, 35(5), 340-349. doi: 10.1057/palgrave.jibs.8400102

Frost, T. (2001). The geographic sources of foreign subsidiaries' innovations. Strategic Management Journal, 22(2), 101-123. doi: 10.1002/1097-0266(200101)22:2<101::AID-SMJ155>3.0.CO;2-G

Garavelli, A. C., Gorgoglione, M., \& Scozzi, B. (2002). Managing knowledge transfer by knowledge technologies. Technovation, 22(5), 269-279. doi: 10.1016/S0166-4972(01)00009-8

Gomes, R. (2003). O papel das subsidiárias e a internacionalização das atividades tecnológicas pelas empresas transnacionais (ETNs). Gestão \& Produção, 10(3), 267-281. doi: 10.1590/S0104$530 X 2003000300004$

Grant, R. M. (1996). Toward a knowledge-based theory of the firm [Special Issue]. Strategic Management Journal, 17, 109-122. doi: 10.2307/2486994 
Gupta, A. K., \& Govindarajan, V. (2000). Knowledge flows within multinational corporations. Strategic Management Journal, 21(4), 473-496. doi: 10.1002/(SICI)10970266(200004)21:4<473::AID-SMJ84>3.0.CO;2-I

Henard, D. H., \& McFadyen, M. A. (2006). R\&D knowledge is power. Research Technology Management, 49(3), 41-47.

Hiratuka, C. (2005). Internacionalização de atividades de pesquisa e desenvolvimento das empresas transnacionais: análise da inserção das filiais brasileiras. São Paulo em Perspectiva, 19(1), 105114. doi: 10.1590/S0102-88392005000100009

Huber, G. P. (1991). Organizational learning: the contributing processes and the literature. Organization Science, 2(1), 88-113. doi: 10.1287/orsc.2.1.88

Keller, R., \& Chinta, R. R. (1990). International technology transfer: strategies for success. Academy of Management Executive, 4(2), 33-43. doi: 10.5465/AME.1990.4274793

Lane, P. J., \& Lubatkin, M. (1998). Relative absorptive capacity and interorganizational learning. Strategic Management Journal, 19(5), 461-477. doi: 10.1002/(SICI)10970266(199805)19:5<461::AID-SMJ953>3.3.CO;2-C

Lane, P. J., Salk, J. E., \& Lyles, M. A. (2001). Absorptive capacity, learning, and performance in international joint ventures. Strategic Management Journal, 22(12), 1139-1161. doi: 10.1002/smj.206.

Lee, T. W. (1998). Using qualitative methods in organizational research. Thousand Oaks, CA: Sage.

Li, D., Ferreira, M. P., \& Serra, F. R.(2009). Technology transfer within MNES: inter-subsidiary competition and cooperation. Revista de Administração e Inovação, 6(1), 139-158. doi: 10.5585/rai.v6i1.288

Lyles, M. A., \& Salk, J. E. (1996). Knowledge acquisition from foreign parents in international joint ventures: an empirical examination in the Hungarian context. Journal of International Business Studies, 27(5), 877-903. doi: 10.1057/palgrave.jibs.8490155

Malhotra, A., Gosain, S., \& Sawy, O. A. (2005). Absorptive capacity configurations in supply chains: gearing for partner-enabled market knowledge creation. MIS Quarterly, 29(1), 145-187.

Martin, X., \& Salomon, R. (2003). Knowledge transfer capacity and its implications of the theory of the multinational corporation. Journal of International Business Studies, 34(4), 356-373. doi: 10.1057/palgrave.jibs.8400037

Minbaeva, D., Pedersen, T., Björkman, I., Fey, C. F., \& Park, H. J. (2003). MNC knowledge transfer, subsidiary absorptive capacity, and HRM. Journal of International Business Studies, 34(6), 586599. doi: $10.1057 /$ palgrave.jibs.8400056

Monteiro, L. F., Arvidsson, N., \& Birkinshaw, J. (2008). Knowledge flows within multinational corporations: explaining subsidiary isolation and its performance implications. Knowledge Organization Science, 19(1), 90-107. doi: 10.1287/orsc.1070.0264

Mudambi, R., \& Navarra, P. (2004). Is knowledge power? Knowledge flows, subsidiary power and rent-seeking within MNCs. Journal of International Business Studies, 35(5), 385-406. doi: 10.1057/palgrave.jibs.8400093

Murovec, N., \& Prodan, I. (2009). Absorptive capacity, its determinants, and influence on innovation output: cross-cultural validation of the structural model. Technovation, 29(12), 859-872. doi: 10.1016/j.technovation.2009.05.010 
Narteh, B. (2008). Knowledge transfer in developed-developing country inter firm collaborations: a conceptual framework. Journal of Knowledge Management, 12(1), 78-91. doi: $10.1108 / 13673270810852403$

Nonaka, I., \& Takeuchi, H. (1997). Criação de conhecimento na empresa: como as empresas japonesas geram a dinâmica da inovação. Rio de Janeiro: Campus.

Noorderhaven, N., \& Harzing, A.-W. (2009). Knowledge-sharing and social interaction within MNEs. Journal of International Business Studies, 40(5), 719-741. doi: 10.1057/jibs.2008

Oliveira, M. M., Jr., Borini, F. M., \& Guevara, A. J. (2009). The strategic relevance of the Brazilian subsidiaries of multinationals corporations. Revista de Administração da USP, 44(4), 285-298.

Orr, S., \& Sohal, A. S. (1999). Technology and global manufacturing: some German experiences. Management Decision, 37(4), 356-363. doi: 10.1108/00251749910269401

Park, Y., \& Kim, S. (2005). Linkage between knowledge management and R\&D management. Journal of Knowledge Management, 9(4), 34-44. doi: 10.1108/13673270510610314

Polanyi, M. (1983). The tacit dimension. Gloucester: Peter Smith.

Rugman, A., \& Verbeke, A. (2001). Subsidiary specific advantages in multinational enterprises. Strategic Management Journal, 22(3), 237-250. doi: 10.1002/smj.153

Scott, J. E. (2000). Facilitating interorganizational learning with information technology. Journal of Management, 17(2), 81-113.

Simonin, B. (2004). An empirical investigation of the process of knowledge transfer in international strategic alliances. Journal of International Business Studies, 35(5), 407-427. doi: 10.1057/palgrave.jibs.8400091

Song, J., \& Shin, J. (2008). The paradox of technological capabilities: a study of knowledge sourcing from host countries of overseas R\&D operations. Journal of International Business Studies, 39(2), 291-303. doi: 10.1057/palgrave.jibs.8400348

Spender, J. C. (1996). Making knowledge the basis of a dynamic theory of the firm [Special Issue]. Strategic Management Journal, 17, 45-62.

Spender, J. C., \& Grant R. M. (1996). Knowledge and the firm: overview. Strategic Management Journal, 17, 5-9.

Szulanski, G. (1996). Exploring internal stickiness: impediments to the transfer of best practice within the firm. Strategic Management Journal, 17(1), 27-43. doi: 10.2307/2486989

Tsoukas, H. (1996). The firm as a distributed knowledge system: a constructionist approach [Special Issue]. Strategic Management Journal, 17, 11-25. doi: 10.2307/2486988

Yin, R. K. (2001). Estudo de caso: planejamento e métodos (2a ed.). Porto Alegre: Bookman.

Zahra, S. A., \& George, G. (2002). Absorptive capacity: a review, re-conceptualization, and extension. Academy of Management Review, 27(2), 185-203. doi: 10.2307/4134351

Zander, U., \& Kogut, B. (1995). Knowledge and the speed of transfer and imitation of organizational capabilities: an empirical test. Organization Science, 6(1), 76-92. doi: 10.1287/orsc.6.1.76 